\title{
Pengembangan Produk Unggulan UMKM Kabupaten Sukabumi
}

\author{
Dikdik Kusdiana \\ Fakultas Ekonomi Universitas Pasundan \\ Jl. Tamansari No. 6-8, Bandung 40116 \\ E-Mail:dkusdiana@yahoo.com \\ Ardi Gunardi \\ Fakultas Ekonomi Universitas Pasundan \\ Jl. Tamansari No. 6-8, Bandung 40116 \\ E-Mail: ardigunardi@unpas.ac.id
}

\begin{abstract}
Micro, Small and Medium enterprises (MSMEs), in national economy, have an important and strategic role. This research examines the main product development of MSMEs in Sukabumi regency. The analysis method used is Analytic Hierarchy Process (AHP). This method is used to identify MSMEs main products in several sectors appropriate to be developed. The result shows that the potential products of MSMEs in each sector, after conducting AHP analysis based on the criteria of uniqueness, market force and economic benefits, are mangosteen, metal processing and workshop services.
\end{abstract}

Keywords: main products of MSMEs, analytic hierarchy process.

\begin{abstract}
ABSTRAK
Usaha mikro, kecil, dan menengah (UMKM) dalam perekonomian nasional memiliki peranan yang penting dan strategis. Penelitian ini ingin mengkaji pengembangan produk unggulan UMKM di Kabupaten Sukabumi. Metode analisis yang digunakan, yaitu Analytic Hierarchy Proccess (AHP) untuk melihat produk unggulan UMKM di berbagai sektor cocok untuk dikembangkan. Hasil penelitian menunjukkan bahwa potensi produk unggulan UMKM di setiap sektor setelah dilakukan analisis AHP berdasarkan kriteria keunikan, potensi pasar, dan manfaat ekonomi, maka dapat diidentifikasi potensi produk unggulan UMKM prioritas adalah manggis, pengolahan logam, dan jasa perbengkelan.
\end{abstract}

Kata Kunci: produk unggulan UMKM, analytic hierarchy process. 


\section{PENDAHULUAN}

Pembangunan ekonomi memiliki tujuan menciptakan kesejahteraan, keadilan, dan kemakmuran bagi masyarakat. Untuk melaksanakan hal tersebut, pemerintah menciptakan berbagai program dan proyek pembangunan untuk meningkatkan taraf hidup masyarakatnya. Penetapan otonomi daerah melalui Undang-undang No. 32 Tahun 2004 tentang otonomi daerah memberikan kewenangan daerah dalam mengurus rumah tangganya sendiri termasuk didalamnyaupayapemerintahdaerahdalampercepatan pembangunan wilayahnya sendiri. Salah satu upaya pemerintah daerah dalam percepatan pembangunan ekonomi dan peningkatan kesejahteraan masyarakat dilakukan melalui pengembangan UMKM.

UMKM dianggap tulang punggung pertumbuhan ekonomi di semua negara. Demirbag et al., (2006) yang menyimpulkan bahwa keberhasilan UMKM memiliki dampak langsung terhadap pembangunan ekonomi baik pada negara maju maupun negara berkembang. Kegiatan UMKM berkontribusi dalam memberikan lapangan kerja, bertindak sebagai pemasok barang dan layanan untuk organisasi besar (Singh et al., 2008). UMKM masih memegang peranan penting dalam pemulihan perekonomian nasional, baik dilihat dari jumlah usaha, segi penciptaan lapangan kerja, maupun dari segi pertumbuhan ekonomi nasional yang diukur dengan Produk Domestik Bruto (PDB).
Berdasarkan data dari Dinas Koperasi dan UMKM tahun 2012 menunjukkan total nilai PDB Indonesia mencapai Rp8.241,8 triliun (Tabel 1). UMKM memberikan kontribusi sebesar Rp. 4.869,5 triliun atau 59,08\% dari total PDB Indonesia. Jumlah populasi UMKM Indonesia pada tahun 2012 mencapai 56,53 juta unit usaha atau 99,99\% terhadap total unit usaha di Indonesia, sementara jumlah tenaga kerjanya mencapai 107,65 juta orang atau $97,16 \%$ terhadap seluruh tenaga kerja Indonesia. Data tersebut menunjukkan bahwa peranan UMKM dalam perekonomian Indonesia sangat penting dalam menyediakan lapangan pekerjaan dan menghasilkan output yang bermanfaat bagi taraf hidup masyarakat.

Peranan UMKM dalam perekonomian nasional sangat penting dan strategis. UMKM berperan dalam pertumbuhan ekonomi dan penyerapan tenaga kerja. Selain itu juga, UMKM mempunyai peran dalam pendistribusian hasil-hasil pembangunan. Keberadaan UMKM tidak hanya dianggap sebagai tempat penampungan sementara bagi para pekerja yang belum masuk ke sektor formal, tetapi juga sebagai motor penggerak pertumbuhan aktivitas ekonomi. Hal ini dikarenakan jumlah penyerapan tenaga kerjanya yang demikian besar. Mengingat pengalaman yang telah dihadapi oleh Indonesia selama krisis ekonomi, kiranya tidak berlebihan apabila pengembangan sektor swasta difokuskan pada UMKM.

Tabel 1. Data Perkembangan UMKM Tahun 2012

\begin{tabular}{|c|c|c|c|c|}
\hline \multirow{2}{*}{ No. } & \multirow{2}{*}{ Indikator } & \multirow{2}{*}{ Satuan } & \multicolumn{2}{|c|}{ Tahun 2012} \\
\hline & & & Jumlah & Pangsa \\
\hline \multirow[t]{6}{*}{1} & Unit Usaha $(A+B)$ & (Unit) & 56.539 .560 & 100 \\
\hline & A. Usaha Mikro, Kecil, dan Menengah (UMKM) & (Unit) & 56.534 .592 & 99,99 \\
\hline & - Usaha Mikro (Umi) & (Unit) & 55.856 .176 & 98,79 \\
\hline & - Usaha Kecil (UK) & (Unit) & 629.418 & 1,11 \\
\hline & - Usaha Menengah (UM) & (Unit) & 48.997 & 0,09 \\
\hline & B. Usaha Besar (UB) & (Unit) & 4.968 & 0,01 \\
\hline \multirow[t]{6}{*}{2} & Tenaga Kerja $(\mathrm{A}+\mathrm{B})$ & (Orang) & 110.808 .154 & 100 \\
\hline & A. Usaha Mikro, Kecil, dan Menengah (UMKM) & (Orang) & 107.657 .509 & 97,16 \\
\hline & - Usaha Mikro (Umi) & (Orang) & 99.859 .517 & 90,12 \\
\hline & - Usaha Kecil (UK) & (Orang) & 4.535 .970 & 4,09 \\
\hline & - Usaha Menengah (UM) & (Orang) & 3.262 .023 & 2,94 \\
\hline & B. Usaha Besar (UB) & (Orang) & 3.150 .645 & 2,84 \\
\hline \multirow[t]{6}{*}{3} & PDB atas Dasar harga Berlaku $(\mathrm{A}+\mathrm{B})$ & (Rp. Milyar) & $8.241864,3$ & 100 \\
\hline & A. Usaha Mikro, Kecil, dan Menengah (UMKM) & (Rp. Milyar) & $4.869 .568,1$ & 59,08 \\
\hline & - Usaha Mikro (Umi) & (Rp. Milyar) & $2.951 .120,6$ & 35,81 \\
\hline & - Usaha Kecil (UK) & (Rp. Milyar) & $798.122,2$ & 9,68 \\
\hline & - Usaha Menengah (UM) & (Rp. Milyar) & $1.120 .325,3$ & 13,59 \\
\hline & B. Usaha Besar (UB) & (Rp. Milyar) & $3.372 .296,1$ & 40,92 \\
\hline
\end{tabular}

Sumber: Kementerian Koperasi dan UKM, 2012 
Perkembangan pesat UMKM juga terjadi di Kabupaten Sukabumi, Jawa Barat. UMKM di Kabupaten Sukabumi sebanyak 21.795 unit usaha mikro, 4.328 unit usaha kecil, dan 877 unit usaha menengah pada tahun 2014, dapat dilihat pada Gambar 1. Sementara itu jika dilihat dari sisi penyerapan tenaga kerja, terdapat total sebanyak 68.668 tenaga kerja yang terdiri dari unit usaha makanan dan minuman, perdagangan dan jasa, kerajinan kulit, rajutan, dan anyaman bambu, dan lainnya (lihat Gambar 2). Kinerja ini tentunya perlu semakin ditingkatkan. Dilihat dari sisi pembinaan terhadap UMKM oleh Pemerintah Daerah Kabupaten Sukabumi, hanya 3.933 UMKM yang telah dibina dari total 27.000 UMKM (lihat Gambar 3). Dengan demikian, keberadaan UMKM di Kabupaten Sukabumi perlu didukung agar lebih menguatkan daya saing pemerintah daerah.

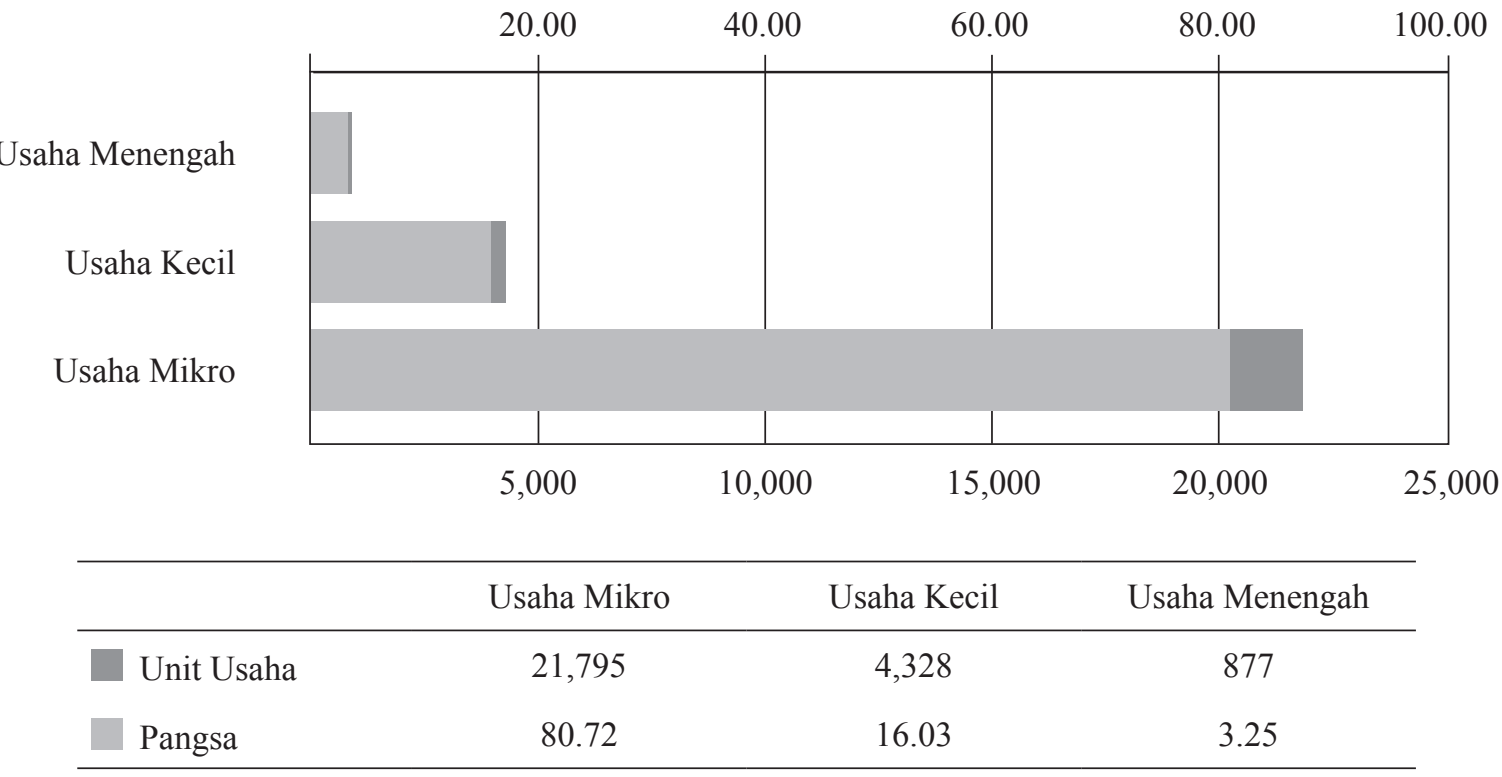

Gambar 1. Jumlah UMKM Kabupaten Sukabumi Berdasarkan Skala Usaha Tahun 2014

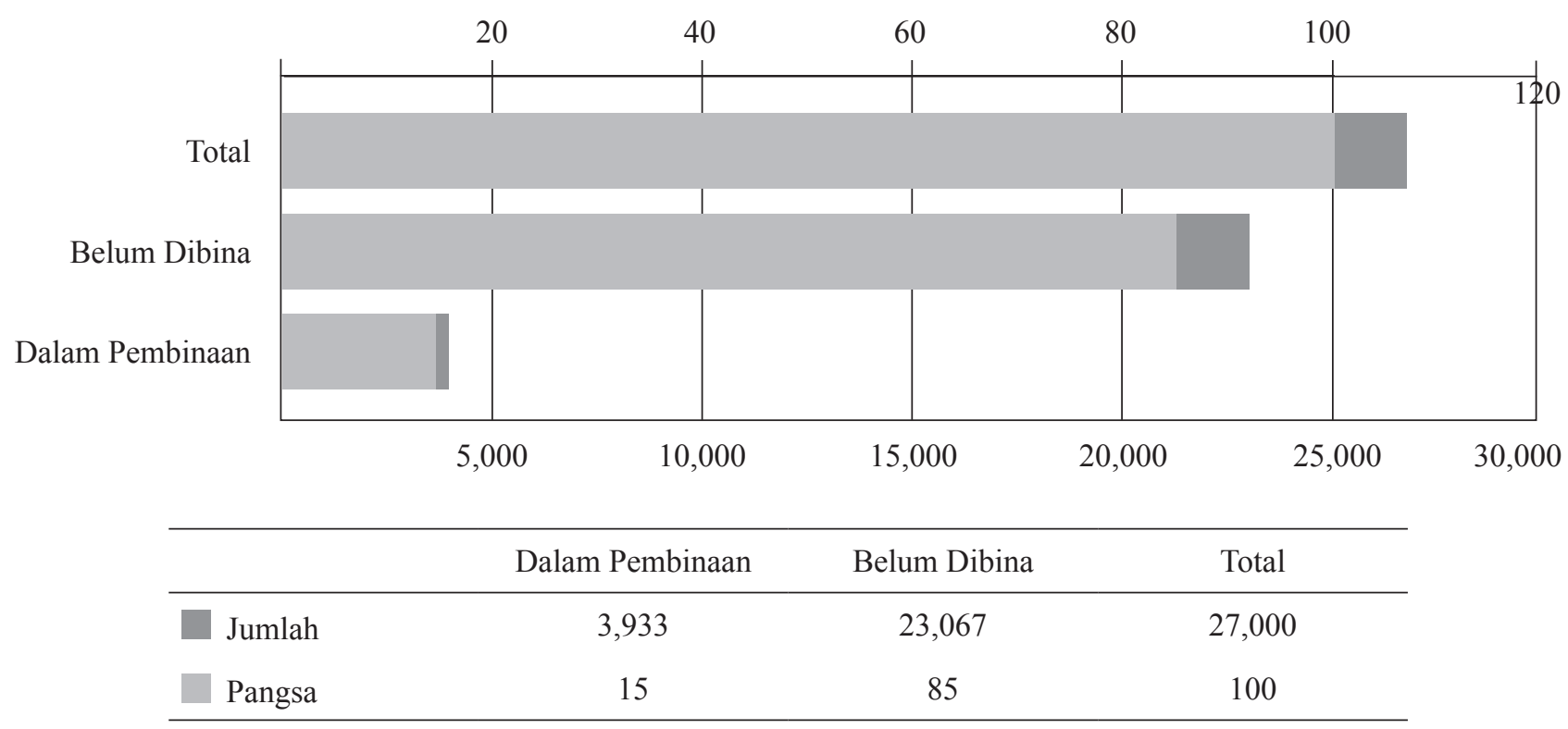

Gambar 2. Jumlah UMKM yang sudah Dibina

Pemerintah Daerah Kabupaten Sukabumi Tahun 2014 


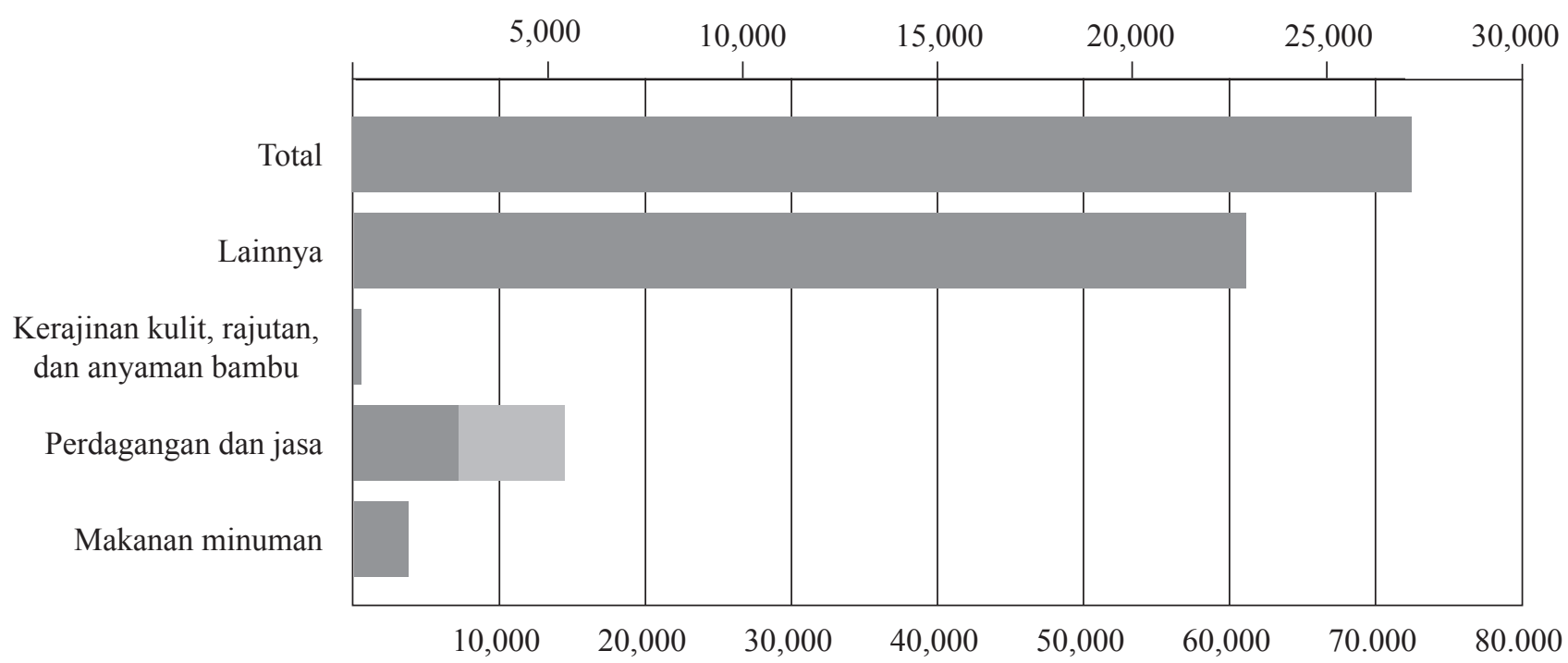

\begin{tabular}{lccccc}
\hline & $\begin{array}{c}\text { Makanan } \\
\text { minuman }\end{array}$ & $\begin{array}{c}\text { Perdagangan } \\
\text { dan jasa }\end{array}$ & $\begin{array}{c}\text { Kerajinan kulit, rajutan, } \\
\text { dan anyaman bambu }\end{array}$ & Lainnya & Total \\
\hline Tenaga Kerja & 2,984 & 13,308 & 520 & 51,856 & 68,668 \\
Unit Usaha & 1,322 & 2,548 & 63 & 23,067 & 27,000 \\
\hline
\end{tabular}

Gambar 3. Jumlah Unit Usaha dan Penyerapan Tenaga Kerja

UMKM Kabupaten Sukabumi Tahun 2014

Selama ini pengembangan unggulan produk UMKM dalam menentukan daftar skala prioritasnya menggunakan kriteria data produksi, pendapat instansi, dan data primer responden UMKM, namun saat ini telah terjadi perubahan yang cukup mendasar, di mana penetapan unggulan produk UMKM di Kabupaten Sukabumi menggunakan Analytic Hierarchy Proccess (AHP), dengan harapan Kabupaten Sukabumi akan mempunyai unggulan produk UMKM di berbagai sektor yang sesuai dan cocok untuk dikembangkan.

Dengan metode AHP ini, maka Pemerintah Daerah Kabupaten Sukabumi dapat menetapkan program yang lebih fokus untuk mengembangkan unggulan produk UMKM, sehingga diharapkan tercipta lapangan pekerjaan dan peningkatan taraf hidup masyarakat, sehingga diharapakan angka kemiskinan akan dapat menurun, dan akan terjadi pertumbuhan ekonomi secara umum. Oleh karena itu, dibutuhkan adanya informasi dari hasil penelitian yang berkaitan dengan pengembangan produk unggulan
UMKM di Kabupaten Sukabumi. Dengan demikian, penelitian ini bertujuan untuk mengidentifikasi upaya pengembangan potensi unggulan produk UMKM yang dapat dilakukan oleh Pemerintah Daerah Kabupaten Sukabumi, sebagai bahan masukan dalam rangka perencanaan pengembangan produk UMKM Kabupaten Sukabumi.

\section{METODE}

Alat analisis yang akan digunakan dalam penelitian ini adalah Analytic Hierarchy Proccess (AHP). AHP membuat proses seleksi yang sangat transparan yang memberikan manfaat relatif dari solusi alternatif untuk masalah Multi Criteria Decision Making (Drake, 1998). Pendekatan AHP juga merupakan metodologi subjektif (Cheng dan Li, 2001), di mana informasi dan bobot prioritas elemen dapat diperoleh dari pembuat keputusan perusahaan menggunakan pertanyaan langsung atau metode kuesioner. 
Prinsip metode AHP adalah memberikan bobot tiap faktor, variabel, dan indikator dengan perbandingan antar faktor, variabel, indikator satu dengan lainnya. Bobot yang lebih besar dari suatu indikator, menunjukkan indikator yang lebih penting dibandingkan indikator lainnya dalam menentukan potensi unggulan produk UMKM. Dalam proses AHP ini dilakukan 3 tahap utama, yaitu pembobotan, klasifikasi intensitas tiap indikator dan penentuan nilai intensitas tiap indikator dan peringkat.

1. Pembobotan terhadap faktor, variabel dan indikator, dilakukan oleh stakeholders ahli (responden) di bidang pengembangan UMKM di tingkat kabupaten dengan menggunakan kuesioner AHP.

2. Langkah pertama yang digunakan adalah pembobotan untuk tujuan. Pembobotan tujuan ini berguna untuk mengetahui faktor apa yang menjadi prioritas tujuan dalam melakukan penguatan UMKM.

3. Pembobotan berikutnya adalah pembobotan kriteria. Pembobotan kriteria dimaksudkan untuk menetapkan kriteria yang akan digunakan dalam pengembangan UMKM di Kabupaten Sukabumi. Pembobotan dilakukan dua kali, yaitu:

a. Memberi bobot pada variabel. Total bobot dalam variabel ini adalah 1 . Semakin besar bobot yang diberikan berarti semakin besar tingkat kepentingan kriteria tersebut.

b. Memberi bobot pada indicator.

4. Matriks bobot sektor/sub sektor setiap distrik sampel. Matriks bobot sektor/sub sektor untuk setiap distrik yang digunakan sebagai sampel ditujukan untuk melihat persepsi para stakeholders di tingkat Kabupaten Sukabumi mengenai kondisi sektor/sub sektor di masingmasing distrik. Bobot yang lebih besar menunjukkan bahwa sektor/sub sektor tersebut lebih potensial dibandingkan sektor yang lain.

5. Pembobotan juga dilakukan di sentra produk unggulan. Sampel yang diambil di masingmasing sentra adalah 2 orang, yaitu staf perekonomian kecamatan (1 orang) dan koperasi yang beranggotakan UMKM (1 orang).

6. Matriks bobot sektor/sub sektor untuk setiap sentra produk unggulan yang digunakan sebagai sampel ditujukan untuk melihat persepsi para stakeholders di tingkat sentra produksi mengenai kondisi sektor/sub sektor di sentra masingmasing.

7. Hasil pembobotan responden diperoleh dengan rata-rata geometris sehingga menghasilkan satu bobot yang sama.

8. Klasifikasi intensitas tiap indikator. Sebelum diolah dengan software, setiap indikator baik yang berasal dari data primer maupun sekunder diklasifikasikan untuk memperoleh intensitas masing-masing. Daftar intensitas indikatorindikator yang berasal hasil olahan data primer berupa persepsi pelaku usaha, dijadikan bahan masukan untuk memperoleh intensitas akhir setiap indikator. Keputusan akhir atas intensitas setiap indikator dari panelis inilah yang selanjutnya akan diolah dengan menggunakan software untuk mendapatkan nilai intensitas tiap indikator dan peringkat potensi unggulan UMKM di Kabupaten Sukabumi.

9. Penentuan nilai intensitas tiap indikator dan peringkat.

\section{HASIL}

\section{Potensi Produk UMKM Kabupaten Sukabumi: Pertanian}

Kabupaten Sukabumi memiliki potensi pada sektor pertanian. Pertanian di Kabupaten Sukabumi terutama tersebar di bagian Utara aliran Sungai Cimandiri. Kondisi ini tidak terlepas dari keberadaan Gunung Gede-Pangrango di sebelah Utara dan Gunung Salak di sebelah Barat. Selain karena didukung kondisi lembah dan lereng di kedua gunung tersebut yang melandai ke arah Selatan juga karena kondisi hutannya yang memberi daya dukung iklim dan tata air yang baik, sehingga daerah pertanian relatif lebih subur dibandingkan daerah pertanian bagian selatan aliran Sungai Cimandiri. Dengan demikian, maka daerah utara berkembang menjadi daerah persawahan, usaha tani sayur-mayur, peternakan dan budidaya ikan air tawar yang cukup potensial.

Kabupaten Sukabumi memiliki komoditi pertanian yang sangat beragam dan tersebar diseluruh kecamatan. Berdasarkan kondisi saat ini yang ada di Kabupaten Sukabumi, komoditi pertanian yang paling diminati oleh UMKM di Kabupaten Sukabumi, potensi yang dimiliki oleh Kabupaten Sukabumi, maupun kondisi permintaan masyarakat 
terhadap komoditi. Maka komoditi sektor pertanian di Kabupaten Sukabumi terbagi menjadi lima prioritas. Lima prioritas komoditi pertanian Kabupaten Sukabumi dapat dilihat pada Tabel 2.

Tabel 2. Prioritas Komoditi Sektor Pertanian di Kabupaten Sukabumi

\begin{tabular}{lc}
\hline \multicolumn{1}{c}{ Komoditi } & Prioritas \\
\hline Manggis & 1 \\
Ikan Hias & 2 \\
Sapi Potong & 3 \\
Ikan Laut & 4 \\
Kelapa & 5 \\
\hline
\end{tabular}

Sumber: Data diolah, 2014

Penggambaran hierarki ini mengikuti logika pendekatan AHP (Saaty, 1994) yang membagi tingkatan struktur dalam hierarkinya sebagai tujuan (goal), sub tujuan, kriteria (criteria), sub kriteria dan alternatif pada tingkatan kriteria yang paling bawah. Dengan menjelaskan bahwa tidak terdapat sub tujuan yang diinginkan, maka hierarki tersebut hanya berisikan tujuan, kriteria, sub kriteria dan alternatif. Dalam membuat hierarki model ini, maka ditentukan:

Tujuan : Menentukan Produk Unggulan UMKM Pertanian

Sub Tujuan : -

Kriteria : Tiga (3) variabel penentuan produk unggulan prioritas

Sub-Kriteria : Sub variabel masing-masing variabel penentuan produk unggulan prioritas

Alternatif : Lima (5) produk unggulan (Gambar 4.)

Berdasarkan Gambar 5., dapat dilihat bahwa pada kriteria keunikan, produk manggis memperoleh bobot skor paling tinggi, yaitu 0,304 atau 30.4\%. Hal ini menyatakan bahwa secara umum keberadaan industri ini mendapatkan perhatian paling tinggi, di antara UKM industri penghasil produk lainnya. Di sisi lain, UKM industri kelapa di Kabupaten Sukabumi, seperti dijelaskan melalui hasil kuesioner bahwa produk ini tidak memiliki keunikan yang signifikan, nilai akhir dengan bobot 0,104 atau $10,4 \%$ saja.

Berdasarkan Gambar 6., dapat dilihat bahwa pada kriteria keunikan, produk manggis masih memperoleh bobot skor paling tinggi, yaitu 0,294 atau 29.4\%.
Hal ini menyatakan bahwa secara umum keberadaan industri ini mendapatkan perhatian paling tinggi, di antara UKM industri penghasil produk lainnya. Di sisi lain, UKM industri kelapa di Kabupaten Sukabumi, seperti dijelaskan melalui hasil kuesioner bahwa produk ini secara aspek pasar masih kurang signifikan, nilai akhir dengan bobot 0,079 atau $7,9 \%$ saja.

Berdasarkan Gambar 7., dapat dilihat bahwa pada kriteria keunikan, produk manggis memperoleh bobot skor paling tinggi, yaitu 0,272 atau $27,2 \%$. Hal ini menyatakan bahwa secara umum keberadaan industri ini mendapatkan perhatian paling tinggi, di antara UKM industri penghasil produk lainnya. Di sisi lain, UKM kelapa di Kabupaten Sukabumi, seperti dijelaskan melalui hasil kuesioner bahwa produk ini secara aspek pasar masih kurang berkontribusi, nilai akhir dengan bobot 0,125 atau $12,5 \%$ saja.

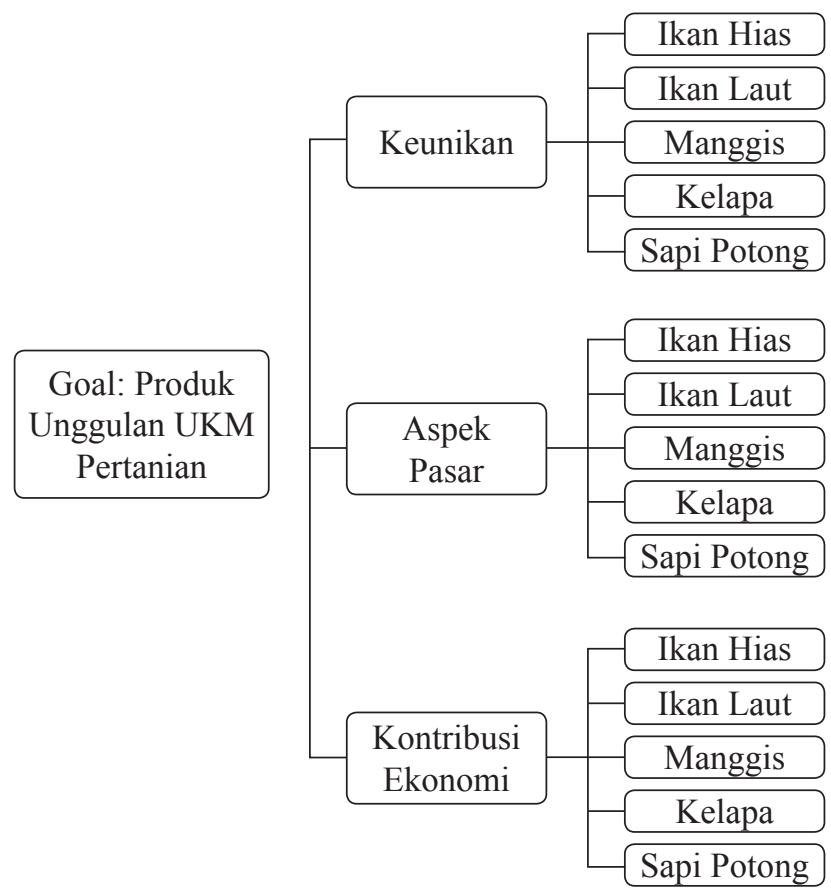

Gambar 4. Alternatif Lima Produk Unggulan UMKM Pertanian

Dengan perlakukan yang sama pada kriteria dan sub kriteria lainnya, maka hasil akhir yang diperoleh dengan menggunakan pendekatan AHP diperlihatkan pada Gambar di bawah ini. Gambar tersebut diperoleh setelah seluruh penilaian terhadap alternatif yang ditetapkan dilakukan terhadap subkriteria dari masing-masing kriteria yang juga telah ditentukan. 
Synthesis with respect to: Keunikan

(Goal: Produk Unggulan UKM > Keunikan (L: 242))

Overall Inconsistency $=.03$

\section{Ikan Hias .276 \\ Ikan Laut . 148 \\ Manggis .304 \\ Kelapa .104 \\ Sapi Potong . 168}

Gambar 5. Produk Unggulan UMKM Pertanian Berdasarkan Kriteria Keunikan

Synthesis with respect to: Aspek Pasar

(Goal: Produk Unggulan UKM > Aspek Pasar (L: 292))

Overall Inconsistency $=.07$

\section{Ikan Hias .259 \\ Ikan Laut .176 \\ Manggis .294 \\ Kelapa .079 \\ Sapi Potong .191}

Gambar 6. Produk Unggulan UMKM Pertanian Berdasarkan Kriteria Aspek Pasar

Synthesis with respect to: Kontribusi Ekonomi (Goal: Produk Unggulan UKM > Kontribusi Ekonomi (L: .1))

Overall Inconsistency $=.04$

\footnotetext{
Ikan Hias . .244

Ikan Laut . .167

Manggis .272

Kelapa .125

Sapi Potong . 192
}

$\begin{array}{rr}\text { Ikan Hias } & .261 \\ \text { Ikan Laut } & .168 \\ \text { Manggis } & .292 \\ \text { Kelapa } & .093\end{array}$

Sapi Potong .186

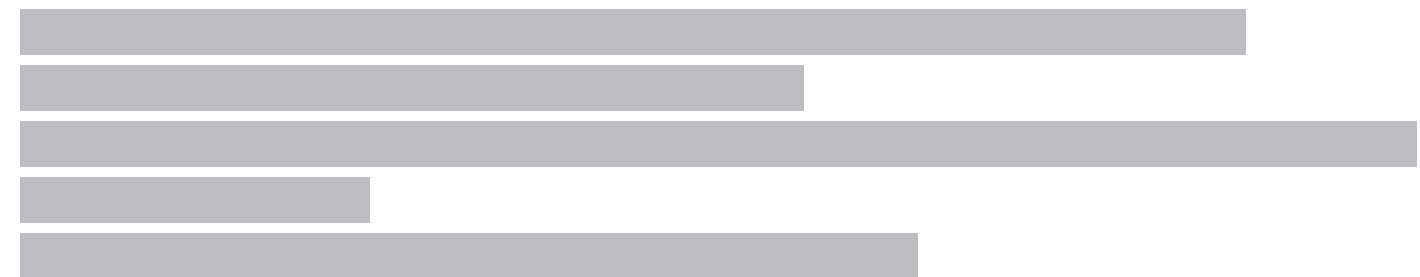

Gambar 7. Produk Unggulan UMKM Pertanian Berdasarkan Kriteria Kontribusi Ekonomi

Synthesis with respect to:

Goal: Produk Unggulan UKM Pertanian

Overall Inconsistency $=.04$

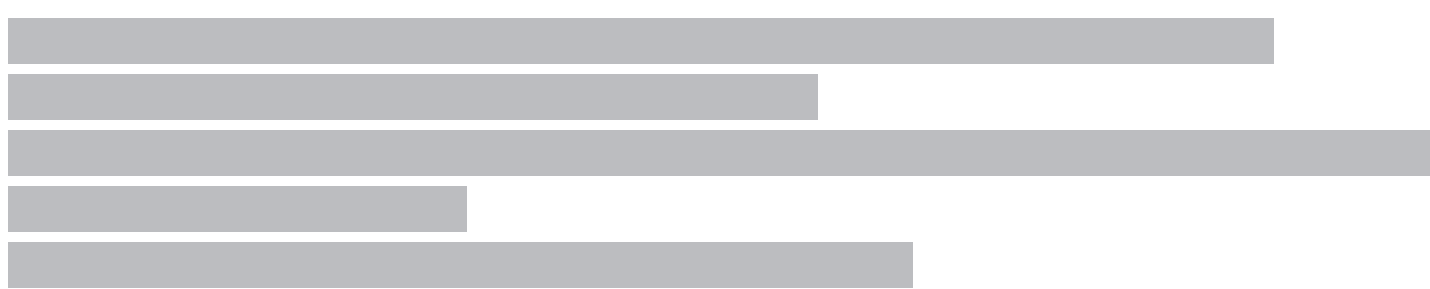

Gambar 8. Produk Unggulan UMKM Pertanian Berdasarkan Pengolahan AHP di Kabupaten Sukabumi 
Berdasarkan hasil tersebut dapat disimpulkan bahwa produk unggulan prioritas yang terpilih adalah (1) manggis dengan bobot sebesar $29,2 \%$ dan (2) ikan hias dengan bobot sebesar 26,1\%. Tampilnya produk manggis menjadi produk peringkat pertama dalam penilaian akhirnya, banyak diperoleh dari indikator keunikan, aspek pasar, dan kontribusi ekonomi. Dengan demikian, produk unggulan UKM di Kabupaten Sukabumi akan diarahkan pada rantai nilai yang dilakukan oleh produk manggis.

\section{Potensi Produk UMKM Kabupaten Sukabumi: Industri Pengolahan}

Kabupaten Sukabumi memiliki komoditi pada sektor industri pengolahan yang sangat beragam dan tersebar diseluruh kecamatan. Berdasarkan kondisi saat ini yang ada di Kabupaten Sukabumi, komoditi sektor industri pengolahan yang paling diminati oleh UMKM di Kabupaten Sukabumi, potensi yang dimiliki oleh Kabupaten Sukabumi, maupun kondisi permintaan masyarakat terhadap komoditi sektor industri pengolahan, maka komoditi sektor industri pengolahan di Kabupaten Sukabumi terbagi menjadi lima prioritas. Berikut ini adalah lima prioritas komoditi industri pengolahan Kabupaten Sukabumi.

Tabel 3. Prioritas Komoditi Sektor Industri Pengolahan di Kabupaten Sukabumi

\begin{tabular}{lc}
\hline \multicolumn{1}{c}{ Komoditi } & Prioritas \\
\hline Logam & 1 \\
Batu Aji & 2 \\
Kerajinan Tanduk & 3 \\
Alat Peraga Pendidikan & 4 \\
Makanan dan Minuman & 5 \\
\hline
\end{tabular}

Sumber: Data diolah, 2014

Penggambaran hierarki ini mengikuti logika pendekatan AHP (Saaty, 1994) yang membagi tingkatan struktur dalam hierarkinya sebagai tujuan (goal), sub tujuan, kriteria (criteria), sub kriteria dan alternatif pada tingkatan kriteria yang paling bawah. Dengan menjelaskan bahwa tidak terdapat sub tujuan yang diinginkan, maka hierarki tersebut hanya berisikan tujuan, kriteria, sub kriteria dan alternatif. Dalam membuat hierarki model ini, maka ditentukan:
Tujuan : Menentukan Produk Unggulan UMKM Industri Pengolahan

Sub Tujuan : -

Kriteria : Tiga (3) variabel penentuan produk unggulan prioritas

Sub-Kriteria: Sub variabel masing-masing variabel penentuan produk unggulan prioritas

Alternatif : Lima (5) produk unggulan

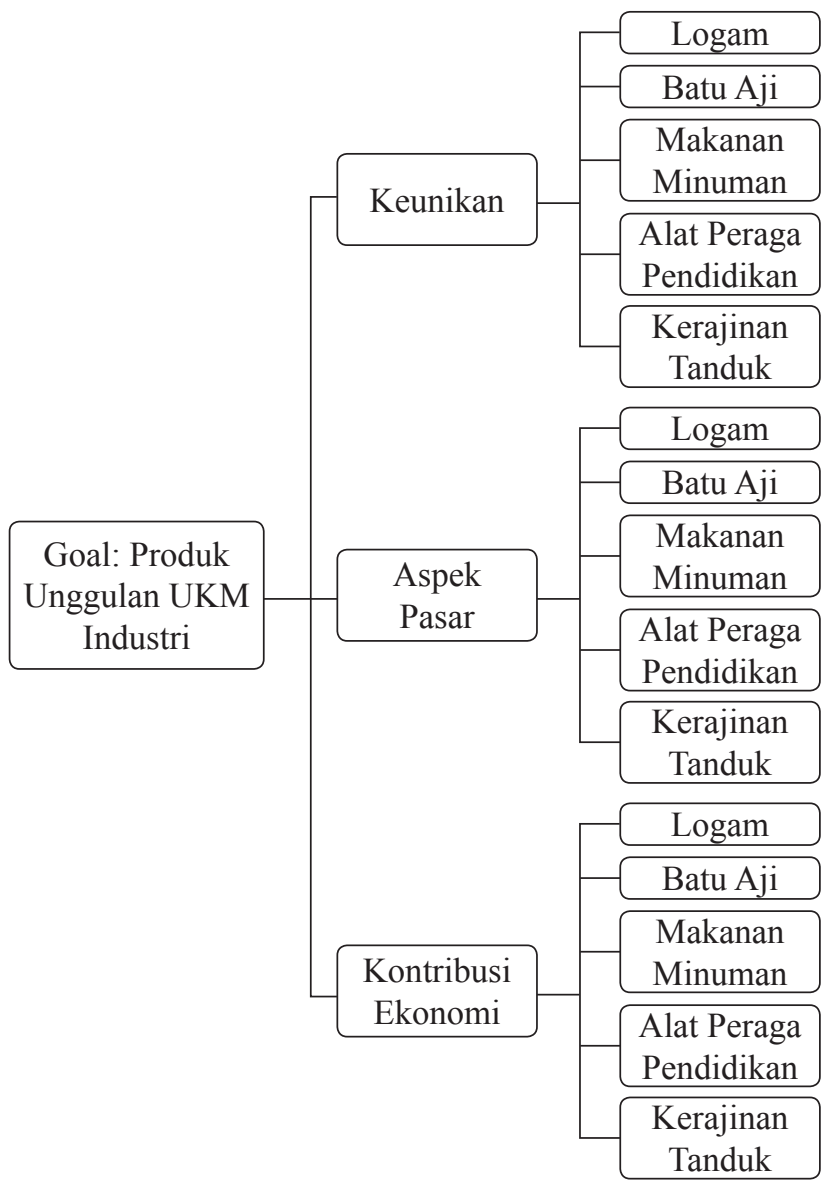

Gambar 9. Alternatif Lima Produk Unggulan UMKM Industri Pengolahan

Berdasarkan Gambar 10., dapat dilihat bahwa pada kriteria keunikan, produk logam memperoleh bobot skor paling tinggi, yaitu 0,368 atau $36.8 \%$. Hal ini menyatakan bahwa secara umum keberadaan industri ini mendapatkan perhatian paling tinggi, di antara UKM industri penghasil produk lainnya. Menurut data yang ada, hal ini dapat diterima mengingat banyaknya pelaku usaha pada industri penghasil logam, seperti: logam, pembuatan alat olah raga, menara mesjid, tapak kuda, pandai besi, besi tua dan gilingan plastik di Kabupaten Sukabumi. 
Synthesis with respect to: Keunikan

(Goal: Produk Unggulan UKM > Keunikan (L: .276))

Overall Inconsistency $=.07$

$\begin{array}{ll}\text { Logam } & .368 \\ \text { Batu Aji } & .245 \\ \text { Makanan dan Minuman } & .096 \\ \text { Alat Peraga Pendidikan } & .137 \\ \text { Kerajinan Tanduk } & .157\end{array}$

Gambar 10. Produk Unggulan UMKM Industri Pengolahan Berdasarkan Kriteria Keunikan

Synthesis with respect to: Aspek Pasar

(Goal: Produk Unggulan UKM > Aspek Pasar (L: .595))

Overall Inconsistency $=.02$

$\begin{array}{ll}\text { Logam } & .347 \\ \text { Batu Aji } & .243 \\ \text { Makanan dan Minuman } & .111 \\ \text { Alat Peraga Pendidikan } & .139 \\ \text { Kerajinan Tanduk } & .160\end{array}$

Gambar 11. Produk Unggulan UMKM Industri Pengolahan Berdasarkan Kriteria Aspek Pasar

Synthesis with respect to: Kontribusi Ekonomi (Goal: Produk Unggulan UKM > Aspek Pasar (L: .1))

Overall Inconsistency $=.05$
Logam
.416
Batu Aji
.210
Makanan dan Minuman .099
Alat Peraga Pendidikan .119
Kerajinan Tanduk
.156

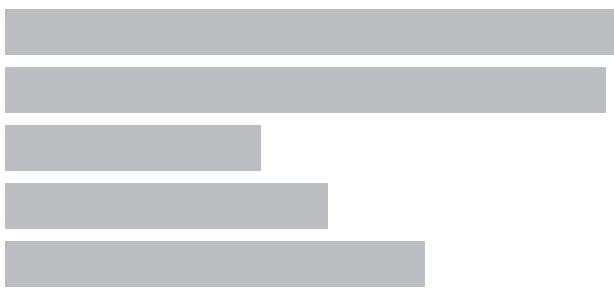

Gambar 12. Produk Unggulan UMKM Industri Pengolahan Berdasarkan Kriteria Kontribusi Ekonomi

Synthesis with respect to

Goal: Produk Unggulan UKM Industri

Overall Inconsistency $=.03$

$\begin{array}{ll}\text { Logam } & .360 \\ \text { Batu Aji } & .240 \\ \text { Makanan dan Minuman } & .106 \\ \text { Alat Peraga Pendidikan } & .135 \\ \text { Kerajinan Tanduk } & .159\end{array}$

Gambar 13. Produk Unggulan UMKM Industri Pengolahan

Berdasarkan Pengolahan AHP di Kabupaten Sukabumi 
Di sisi lain, UKM industri makanan dan minuman di Kabupaten Sukabumi, seperti dijelaskan melalui hasil kuesioner bahwa produk ini tidak memiliki keunikan yang signifikan, nilai akhir dengan bobot 0,096 atau $9,6 \%$ saja.

Berdasarkan Gambar 11., dapat dilihat bahwa pada kriteria keunikan, produk logam masih memperoleh bobot skor paling tinggi, yaitu 0,347 atau $34.7 \%$. Hal ini menyatakan bahwa secara umum keberadaan industri ini mendapatkan perhatian paling tinggi, di antara UMKM industri penghasil produk lainnya. Menurut data yang ada, hal ini dapat diterima mengingat banyaknya pelaku usaha pada industri penghasil logam, seperti: logam, pembuatan alat olah raga, menara mesjid, tapak kuda, pandai besi, besi tua dan gilingan plastik di Kabupaten Sukabumi. Di sisi lain, UMKM industri makanan dan minuman di Kabupaten Sukabumi, seperti dijelaskan melalui hasil kuesioner bahwa produk ini secara aspek pasar masih kurang signifikan, nilai akhir dengan bobot 0,111 atau $11,1 \%$ saja.

Berdasarkan Gambar 12., dapat dilihat bahwa pada kriteria keunikan, produk logam memperoleh bobot skor paling tinggi, yaitu 0,416 atau $41,6 \%$. Hal ini menyatakan bahwa secara umum keberadaan industri ini mendapatkan perhatian paling tinggi, di antara UMKM industri penghasil produk lainnya. Menurut data yang ada, hal ini dapat diterima mengingat banyaknya pelaku usaha pada industri penghasil logam, seperti: logam, pembuatan alat olah raga, menara mesjid, tapak kuda, pandai besi, besi tua dan gilingan plastik di Kabupaten Sukabumi. Di sisi lain, UMKM industri makanan dan minuman di Kabupaten Sukabumi, seperti dijelaskan melalui hasil kuesioner bahwa produk ini secara aspek pasar masih kurang berkontribusi, nilai akhir dengan bobot 0,099 atau $9,9 \%$ saja.

Dengan perlakukan yang sama pada kriteria dan sub kriteria lainnya, maka hasil akhir yang diperoleh dengan menggunakan pendekatan AHP diperlihatkan pada Gambar di bawah ini. Gambar tersebut diperoleh setelah seluruh penilaian terhadap alternatif yang ditetapkan dilakukan terhadap sub-kriteria dari masing-masing kriteria yang juga telah ditentukan.

Berdasarkan hasil tersebut dapat disimpulkan bahwa produk unggulan prioritas yang terpilih adalah (1) logam dengan bobot sebesar 36,0\% dan (2) batu aji dengan bobot sebesar $24,0 \%$. Tampilnya produk logam menjadi produk peringkat pertama dalam penilaian akhirnya, banyak diperoleh dari indikator keunikan, aspek pasar, dan kontribusi ekonomi. Dengan demikian, produk unggulan UKM di Kabupaten Sukabumi akan diarahkan pada rantai nilai yang dilakukan oleh industri logam.

\section{Potensi Produk UMKM Kabupaten Sukabumi: Perdagangan dan Jasa}

Kabupaten Sukabumi memiliki komoditi pada sektor perdagangan dan jasa yang sangat beragam dan tersebar diseluruh kecamatan. Berdasarkan kondisi saat ini yang ada di Kabupaten Sukabumi, komoditi sektor perdagangan dan jasa yang paling diminati oleh UMKM di Kabupaten Sukabumi, potensi yang dimiliki oleh Kabupaten Sukabumi, maupun kondisi permintaan masyarakat terhadap komoditi sektor perdagangan dan jasa, maka komoditi sektor perdagangan dan jasa di Kabupaten Sukabumi terbagi menjadi lima prioritas. Berikut ini adalah lima prioritas komoditi perdagangan dan jasa Kabupaten Sukabumi.

Tabel 4. Prioritas Komoditi Sektor

Perdagangan dan Jasa di Kabupaten Sukabumi

\begin{tabular}{lc}
\hline \multicolumn{1}{c}{ Komoditi } & Prioritas \\
\hline Jasa Perbengkelan & 1 \\
Pedagang Eceran & 2 \\
Penjahit & 3 \\
Percetakan & 4 \\
Salon & 5 \\
\hline
\end{tabular}

Sumber: Data diolah, 2014

Penggambaran hierarki ini mengikuti logika pendekatan AHP (Saaty, 1994) yang membagi tingkatan struktur dalam hierarkinya sebagai tujuan (goal), sub tujuan, kriteria (criteria), sub kriteria dan alternatif pada tingkatan kriteria yang paling bawah. Dengan menjelaskan bahwa tidak terdapat sub tujuan yang diinginkan, maka hierarki tersebut hanya berisikan tujuan, kriteria, sub kriteria dan alternatif. Dalam membuat hierarki model ini, maka ditentukan:

Tujuan : Menentukan Produk Unggulan UMKM Perdagangan dan Jasa

Sub Tujuan : -

Kriteria : Tiga (3) variabel penentuan produk unggulan prioritas

Sub-Kriteria: Sub variabel masing-masing variabel penentuan produk unggulan prioritas

Alternatif : Lima (5) produk unggulan 


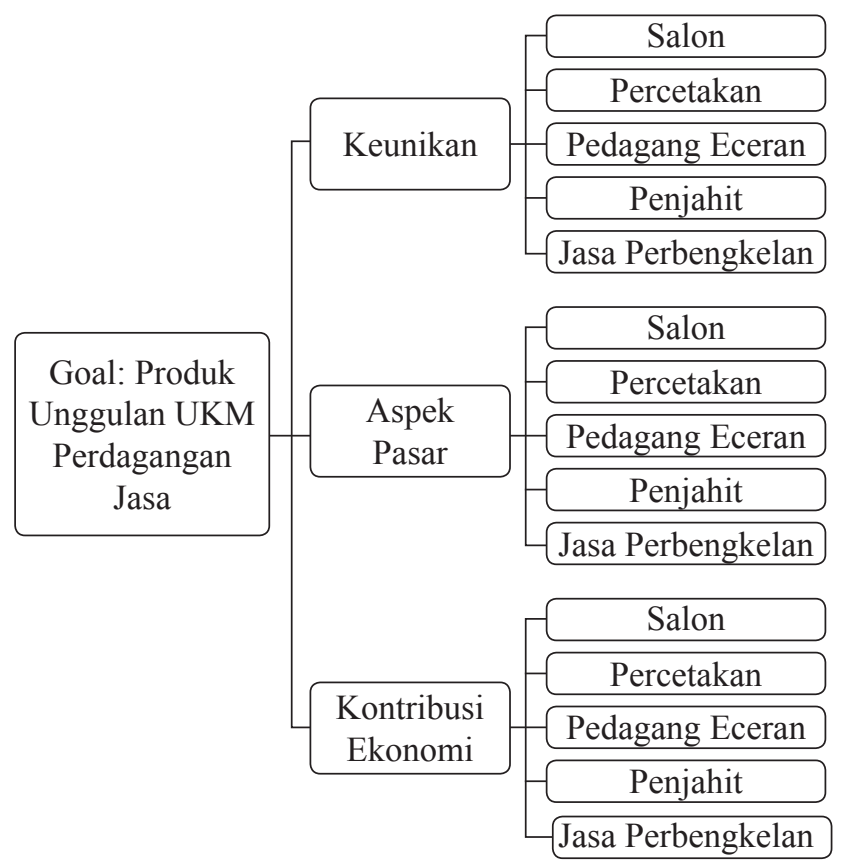

Gambar 14. Alternatif Lima Produk Unggulan UMKM Perdagangan dan Jasa
Berdasarkan Gambar 15., dapat dilihat bahwa pada kriteria keunikan, jasa perbengkelan memperoleh bobot skor paling tinggi, yaitu 0,323 atau $32.3 \%$. Hal ini menyatakan bahwa secara umum keberadaan industri ini mendapatkan perhatian paling tinggi, di antara UKM industri penghasil produk lainnya. Di sisi lain, UKM jasa salon di Kabupaten Sukabumi, seperti dijelaskan melalui hasil kuesioner bahwa jasa ini tidak memiliki keunikan yang signifikan, nilai akhir dengan bobot 0,107 atau $10,7 \%$ saja.

Berdasarkan Gambar 16., dapat dilihat bahwa pada kriteria keunikan, jasa perbengkelan masih memperoleh bobot skor paling tinggi, yaitu 0,242 atau $24.2 \%$. Hal ini menyatakan bahwa secara umum keberadaan industri ini mendapatkan perhatian paling tinggi, di antara UKM industri penghasil produk lainnya. Di sisi lain, UKM jasa salon di Kabupaten Sukabumi, seperti dijelaskan melalui hasil kuesioner bahwa produk ini secara aspek pasar masih kurang signifikan, nilai akhir dengan bobot 0,158 atau $15,8 \%$ saja.

Synthesis with respect to: Keunikan

(Goal: Produk Unggulan UKM Industri > Keunikan (L: .331))

Overall Inconsistency $=.04$

Salon
Percetakan
Pedagang Eceran
Penjahit
Jasa Perbengkelan

.107
.141
.245
.185
.323

Gambar 15. Produk Unggulan UMKM Perdagangan dan Jasa

Berdasarkan Kriteria Keunikan

Synthesis with respect to: Aspek Pasar

(Goal: Produk Unggulan UKM Industri > Aspek Pasar (L: .379))

Overall Inconsistency $=.09$

Salon
Percetakan
Pedagang Eceran
Penjahit
Jasa Perbengkelan

.158

.194

.207

.198

.242
Gambar 16. Produk Unggulan UMKM Perdagangan dan Jasa Berdasarkan Kriteria Aspek Pasar 


$\begin{array}{ll}\text { Salon } & .112 \\ \text { Percetakan } & .157 \\ \text { Pedagang Eceran } & .240 \\ \text { Penjahit } & .222 \\ \text { Jasa Perbengkelan } & .268\end{array}$

Gambar 17. Produk Unggulan UMKM Perdagangan dan Jasa Berdasarkan Kriteria Kontribusi Ekonomi

Synthesis with respect to:

Goal: Produk Unggulan UKM Perdagangan dan Jasa

Overall Inconsistency $=.05$

.130
.168
.228
.202
.272

Gambar 18. Produk Unggulan UMKM Perdagngan dan Jasa Berdasarkan Pengolahan AHP di Kabupaten Sukabumi
Berdasarkan Gambar 17., dapat dilihat bahwa pada kriteria keunikan, jasa perbengkelan memperoleh bobot skor paling tinggi, yaitu 0,268 atau $26,8 \%$. Hal ini menyatakan bahwa secara umum keberadaan industri ini mendapatkan perhatian paling tinggi, di antara UKM industri penghasil produk lainnya. Di sisi lain, UKM jasa salon di Kabupaten Sukabumi, seperti dijelaskan melalui hasil kuesioner bahwa produk ini secara aspek pasar masih kurang berkontribusi, nilai akhir dengan bobot 0,112 atau 11,2\% saja.

Dengan perlakukan yang sama pada kriteria dan sub kriteria lainnya, maka hasil akhir yang diperoleh dengan menggunakan pendekatan AHP diperlihatkan pada Gambar di bawah ini. Gambar tersebut diperoleh setelah seluruh penilaian terhadap alternatif yang ditetapkan dilakukan terhadap sub-kriteria dari masing-masing kriteria yang juga telah ditentukan.

Berdasarkan hasil tersebut dapat disimpulkan bahwa produk unggulan prioritas yang terpilih adalah (1) jasa perbengkelan dengan bobot sebesar 27,2\% dan (2) pedagang eceran dengan bobot sebesar $22,8 \%$. Tampilnya jasa perbengkelan menjadi produk peringkat pertama dalam penilaian akhirnya, banyak diperoleh dari indikator keunikan, aspek pasar, dan kontribusi ekonomi (lihat Lampiran Pengolahan AHP). Dengan demikian, produk unggulan UKM di Kabupaten Sukabumi akan diarahkan pada rantai nilai yang dilakukan oleh jasa perbengkelan.

\section{PEMBAHASAN}

\section{Prioritas Produk Unggulan UMKM Pertanian}

Untuk mengoptimalkan potensi pertanian yang dimiliki oleh Kabupaten Sukabumi, masyarakat Kabupaten Sukabumi sebagian besar lebih memilih untuk menanam buah manggis. Manggis merupakan salah satu ciri khas buah Asia Tenggara, dan buah unggulan Indonesia yang memiliki peluang ekspor yang cukup menjanjikan.

Jika dilihat dari tahun ke tahun permintaan manggis meningkat seiring dengan kebutuhan konsumen terhadap buah yang mendapat julukan "Queen of Fruits", baik untuk konsumen dalam negeri maupun ekspor. Ekspor manggis di Indonesia mengalami peningkatan. Volume ekspor buah manggis segar dalam 5 (lima) tahun terakhir bervariasi, dan pada 
tahun 2006 mencapai 5.698 ton senilai 3,6 juta US\$. Rata-Rata persentase ekspor manggis dibandingkan ekspor buah total dari tahun 2002-2006 adalah sebesar 34,3\% (Ditjen Hortikultura, 2008). Peluang ekspor manggis masih terbuka, karena pasar buahbuahan termasuk manggis belum dibatasi oleh kuota. Di Indonesia, hingga saat ini buah manggis telah di ekspor ke negara Taiwan, Hongkong, Singapura, Malaysia, Jepang, Belanda, dan Arab Saudi.

Saat ini keberadaan manggis di Kabupaten Sukabumi menjadi isu utama daerah yang sedang hangat diperbincangkan oleh masyarakat Kabupaten Sukabumi maupun pemerintah daerah dan pusat. Manggis Kabupaten Sukabumi menjadi wilayah andalan manggis di Jawa Barat selain di Kabupaten Tasikmalaya, Purwakarta, Bogor, Ciamis, dan Cianjur (Ditjen Bina Produksi Hortikultura, 2004). Di Kabupaten Sukabumi, sentra manggis salah satunya berada di Kecamatan Cikembar. Produksi manggis di Kabupaten Sukabumi dari tahun ke tahun mengalami peningkatan. Data dari Dinas Pertanian dan Tanaman Pangan (DPTP) Kabupaten Sukabumi menyebutkan, pada 2012 lalu produksi manggis mencapai sebanyak 22.329 ton.

Selain buah manggis sebagai komoditi utama yang paling diminati oleh para UMKM di Kabupaten Sukabumi, sebagian besar masyarakat Kabupaten Sukabumi juga melakukan budidaya ikan hias. Ikan hias menjadi pilihan kedua produk UMKM di Kabupaten Sukabumi. Ikan hias cukup dikenal oleh masyarakat sebagai hiasan aquarium dan hobi. Perkembangan ikan hias di Indonesia mengalami kemajuan yang terus meningkat hingga awal tahun 2014, terutama jenis ikan hias air tawar asli Indonesia. Peningkatan tersebut menyebabkan Indonesia kini merupakan negara pengekspor ikan hias terbesar di 5 besar di dunia Ikan hias yang di ekspor kebanyakan berasal dari para peternak ikan hias di Jawa Barat. Kabupaten Sukabumi merupakan salah satu pengekspor ikan hias terbesar di wilayah Jawa Barat, bahkan di Indonesia. Ikan hias yang menjadi andalan Kabupaten Sukabumi, yaitu ikan koi.

Sementara itu, komoditi pertanian di Kabupaten Sukabumi yang diminati selain manggis dan ikan hias, sapi potong menjadi komoditi pertanian yang diminati oleh para UMKM di Kabupaten Sukabumi. Hal ini mengingat bahwa Kabupaten Sukabumi memiliki hamparan ladang rumput yang sangat luas, sehingga hal tersebut sangat mendukung pengembangan sapi potong di Kabupaten Sukabumi. Selain itu, saluran irigasi di Kabupaten Sukabumi pun sangat baik. Dengan demikian, peternakan sapi potong sangat cocok diterapkan di Kabupaten Sukabumi.

Selain memiliki kondisi alam yang sangat mendukung pengembangan sektor pertanian, Kabupaten Sukabumi juga memiliki potensi sumber daya pesisir dan kelautan terutama tersebar ke dalam 7 (tujuh) wilayah kecamatan yang berbatasan langsung dengan Samudera Indonesia, yaitu sepanjang \pm 117 $\mathrm{km}$ yang memanjang dari wilayah kecamatan Cisolok, Palabuhanratu, Ciemas, Ciracap, Surade, Cibitung, dan Tegalbuleud.

Dengan potensi tersebut, banyak UMKM di Kabupaten Sukabumi yang memilih bergerak pada komoditi ikan laut. Hal ini mengingat bahwa permintaan pasar terhadap ikan laut diberbagai daerah bahkan dunia sangat tinggi. Saat ini, ikan laut Kabupaten Sukabumi merupakan salah satu daerah penghasil ikan laut andalan Jawa Barat. Komoditi ikan laut Kabupaten Sukabumi selain dipasarkan di lokal kabupaten dan provinsi, ikan laut Kabupaten Sukabumi juga menyuplai permintaan ikan laut nasional bahkan internasional.

Terakhir, komoditi pertanian yang paling diminati oleh UMKM di Kabupaten Sukabumi adalah kelapa. Para UMKM Kabupaten Sukabumi banyak yang menanam kelapa. Hal ini mengingat bahwa permintaan kelapa di lokal Kabupaten Sukabumi sangat tinggi. Tingginya permintaan kelapa di Kabupaten Sukabumi karena kelapa Kabupaten Sukabumi memiliki kualitas yang cukup baik. Daerah di Kabupaten Sukabumi yang memiliki permintaan kelapa terbesar berada di daerah pesisir Kabupaten Sukabumi. Hal ini disebabkan karena banyak wisatawan yang ingin makan dan minum es kelapa muda setelah melakukan berjemur, berenang ataupun ketika mereka mengunjungi pantai di Kabupaten Sukabumi. Selain tingginya permintaan kelapa yang berasal dari lokal Kabupaten, kelapa Kabupaten Sukabumi diminati oleh berbagai daerah di Jawa Barat maupun daerah sekitar Kabupaten Sukabumi, seperti provinsi DKI Jakarta dan Banten. Bahan kelapa Kabupaten Sukabumi terkadang harus memenuhi kebutuhan permintaan kelapa nasional yang hingga kini permintaan kelapa di tingkat nasional semakin meningkat.

Secara umum analisis rantai nilai dari produk manggis dapat dijabarkan sebagai berikut: 


\section{Aktivitas Utama}

a. Logistik ke Dalam (Inbound Logistics)

Ketersediaan bahan baku untuk produksi di dapat dari pasar-pasar tradisional yang ada di Kabupaten Sukabumi, hingga saat ini tidak pernah mengalami kesulitan dalam mendapatkan bahan baku tersebut, meskipun ada beberapa bahan baku khusus yang didatangkan dari luar Kabupaten Sukabumi, seperti pupuk dan pestisida dapat disediakan oleh beberapa pengusaha yang ada di Kabupaten Sukabumi. Lokasi perkebunan manggis pada dasarnya masih merupakan usaha perorangan atau kelompok dan berlokasi di lingkungan lahan pertanian milik masyarakat Kabupaten Sukabumi.

b. Operasi/Produksi

Produksi-produksi pada saat ini sebagian besar masih menggunakan peralatan secara manual dan tradisional yang berkembang secara turun-temurun. Produksi manggis sebagaimana produk pertanian lainnya sangat tergantung pada musim. Kekhasan produk manggis Kabupaten Sukabumi, secara kualitas hasil panen lebih bagus dibandingkan manggis yang dihasilkan daerah lain. Pengetahuan mengenai teknologi tanam yang mudah difragmentasi oleh pelaku usaha baru, sehingga berpotensi menimbulkan citra daerah sebagai penghasil manggis.

c. Logistik ke Luar (Outbound Logistics)

Produk manggis yang dihasilkan dijual langsung ke pasar atau melalui pedagang pengumpul yang berasal dari wilayah Sukabumi maupun dari luar wilayah Kabupaten Sukabumi.

d. Pemasaran dan Penjualan

Akses informasi pasar masih terbatas pada pameran-pameran yang diadakan oleh dinas terkait. Pangsa pasar di daerah masih cukup besar dan memiliki peluang yang cukup besar untuk dikembangkan ke luar daerah. Untuk pasar internasinal, manggis di Kabupaten Sukabumi dipasarkan melalui pedagang besar yang berada di Jakarta.

e. Pelayanan

Penjaminan kualitas produk yang dijual dilakukan melalui penyortiran produk berdasarkan kualitas dan ukuran, menimbulkan kebutuhan pelatihan bagi tenaga kerja untuk meningkatkan keterampilan pasca panen.

\section{Aktivitas Pendukung}

a. Infrastruktur Perusahaan

Infrastruktur pendukung budi daya manggis

Kabupaten Sukabumi, pada dasarnya melingkupi sarana akses jalan darat menuju lokasi perkebunan di Kabupaten Sukabumi. Kondisi inftastruktur transportasi cukup mendukung distribusi hasil produksi.

b. Manajemen Sumber Daya Manusia (MSDM)

Kinerja SDM dalam budidaya manggis membutuhkan tenaga kerja dengan keterampilan yang dimiliki secara turun-temurun. Pekerja berasal dari masyarakat sekitar dengan kriteria unskilled maupun skilled yang kemudian dilatih secara langsung atau dituntun oleh pekerja yang sudah lama berkerja di lahan perkebunan.

Penerapan manajemen usaha sederhana dan bersifat tradisional/usaha keluarga. Dapat dijadikan usaha andalan/mata pencaharian masyarakat dalam pemberdayaan ekonomi kerakyatan terutama bagi masyarakat petani sebagai alternatif kegiatanekonomi bernilai tambah tinggi.

c. Pengembangan Teknologi

Pengembangan budi daya produksi menggunakan teknologi yang relatif lambat berkembang dan lebih banyak menggunakan proses produksi secara manual dan tradisional. Sistem penyediaan dan pelatihan tenaga kerja dapat diperoleh di lingkungan industri tersebut. Terdapat beberapa IKM yang menampung siswi-siswi SMK dari daerah sekitarnya untuk melakukan praktik kerja lapangan.

Kutlu dan Özturan (2008), berpendapat bahwa dalam UMKM, pengembangan teknologi informasi dan komunikasi dapat digunakan sebagai alat bisnis untuk mengurangi biaya, membuat link kuat dengan pelanggan, membuat inovasi dan memfasilitasi ceruk pasar. Ongori (2009) juga menyatakan bahwa UMKM dipaksa untuk mengadopsi teknologi informasi dan komunikasi dalam proses bisnis mereka dalam rangka untuk mengatasi tantangan dalam lingkungan bisnis.

d. Pengadaan Barang

Pengadaan bahan baku dilakukan sesuai kebutuhan. Ketersediaan bahan baku di pasar-pasar lokal di Kabupaten Sukabumi membuat jaminan bahan baku terjaga. Bahan-bahan khusus yang didatangkan dari luar Kabupaten Sukabumi juga sudah tertata dalam jaringan usaha yang baik.

Tidak terdapat gudang penyimpanan untuk menyimpan bahan baku dalam waktu yang panjang karena bahan baku yang ada langsung digunakan. Terdapat gudang penyimpanan hasil produksi untuk sementara yang cukup memadai.

Dari penjelasan yang telah disampaikan, maka dapat diperoleh kesimpulan awal dari rantai nilai 
budi daya manggis adalah bahwa sub aktivitas yang memberikan kontribusi nilai tambah yang penting di Kabupaten Sukabumi berasal dari aktivitas utama dan pendukung. Sub aktivitas utama yang memberikan kontribusi penting dalam penciptaan nilai tambah adalah sub aktivitas operasi/produksi, sedangkan sub aktivitas pendukung berasal dari manajemen SDM yang sangat berkaitan dengan proses produksi yang dilakukan. Dengan justifikasi ini, maka dipilihlah aktivitas rantai nilai proses produksi sub aktivitas operasi/produksi dan aktivitas manajemen SDM.

\section{Prioritas Produk Unggulan UMKM Industri Pengolahan}

Logam menjadi salah satu produk unggulan industri dari Kabupaten Sukabumi. Produk logam Sukabumi dinilai cukup berkualitas dan sudah terkenal hingga ke luar daerah. Terpilih logam sebagai produk industri unggulan daerah. Hal ini didasarkan sejumlah pertimbangan antara lain sudah terdapat beberapa sentra pembuatan logam yang tersebar ke dalam 21 kecamatan. Data dari Diskopperindag Kabupaten Sukabumi, keberadaan Industri Logam dan Mesin (ILM) di Sukabumi tersebar ke dalam 21 kecamatan, diantaranya: Kecamatan Cisaat, Nagrak, Sukaraja, Nyalindung, Jampang Kulon, Cibitung, dan Kebon Pedes. Pelaku usaha yang bergerak di logam mencapai sebanyak 786 unit usaha. Sebagian besar diantaranya berada di kawasan Cibatu, Kecamatan Cisaat sebanyak 167 unit usaha.

Peluang pasar industri logam di Sukabumi cukup besar. Saat ini produk logam Sukabumi mayoritas untuk pembuatan alat pertanian, kesehatan, dan suku cadang otomotif. Kabupaten Sukabumi memiliki potensi sumber daya alam dan pengrajin batu aji yang berlimpah. Sejak dahulu, produk batu aji Kabupaten Sukabumi dikenal luas masyarakat dan permintaan batu aji Kabupaten Sukabumi terus mengalami peningkatan setiap tahunnya. Salah satu daerah yang menjadi sentra batu aji berada di Kecamatan Sukaraja. Hal ini merupakan potensi yang harus dikembangkan. Sebagai barang berharga yang banyak diminati, saat ini batu aji tidak hanya berupa batu cincin saja, tetapi juga dalam bentuk berbagai jenis barang, mulai dari perhiasan wanita, cenderamata, dan berbagai barang kerajinan lainnya.

Sebelumnya para pelaku usaha batu aji telah mendapatkan berbagai pelatihan dan pembinaan dari pemerintah daerah pusat dan daerah. Jumlah para pelaku usaha yang berada di Kabupaten Sukabumi mencapai sebanyak 1.075. Nilai investasi para pelaku usaha batu aji cukup besar mencapai sekitar Rp 25,5 miliar dan mampu menyerap ribuan pekerja.

Selain terkenal dengan batu ajinya, Kabupaten Sukabumi juga terkenal dengan kerajinan tanduknya. Kerajinan tanduk Kabupaten Sukabumi telah terkenal di berbagai daerah bahkan mancanegara. Kerajinan tanduk terbuat dari tanduk kerbau yang bisa diukir, sehingga menghasilkan bentuk yang menarik mulai dari bentuk burung, ikan, penggaruk, sendok, garpu, gantungan kunci, sisir, dan lain-lain.

Pemasaran tanduk Kabupaten Sukabumi sudah menembus pasar internasional. Negara di berbagai dunia, seperti Jerman, Jepang, Australia, dan Korea memesan kerajinan tanduk untuk dijadikan bingkai kacamata Rodenstock. Jerman merupakan negara yang paling berminat terhadap kerajinan tanduk. Namun demikan, karena keterbatasan sumber bahan baku, tidak semua permintaan bisa dipenuhi oleh para pengrajin tanduk di Kabupaten Sukabumi. Selain itu, para pengrajin tanduk di Kabupaten Sukabumi pun terus mengalami penurunan.

Selain itu, industri alat peraga pendidikan Kabupaten Sukabumi juga terkenal di berbagai daerah di Indonesia. Industri alat peraga Kabupaten Sukabumi telah menembus pasar mancanegara. Apalagi kini permintaan alat peraga pendidikan baik di dalam negeri maupun mancanegara semakin meningkat. Jenis alat peraga pendidikan di Kabupaten Sukabumi diantaranya, yaitu puzzle, rambu lalu lintas, abacus (bola lima tiang), geometri, dan alat peraga pendidikan lainnya. Salah satu daerah di Kabupaten Sukabumi yang memproduksi alat peraga pendidikan, yaitu berada di Kampung Paledang Desa Cimahi Kecamatan Cicantayan.

Daya serap industri alat peraga pendidikan cukup besar, sehingga dapat mengurangi tingkat pengangguran di Kabupaten Sukabumi. Selain itu omzet industri alat peraga pendidikan di Kabupaten Sukabumi sangat menjanjikan. Dengan potensi tersebut, hal itu menjadi peluang bagi para UMKM di Kabupaten Sukabumi untuk mengembangkan industri alat peraga pendidikan.

Industri makanan Kabupaten Sukabumi sangat beragam jenisnya diantaranya, yaitu kue mochi, rangginang, aneka kue kering dan basah, manisan, dan berbagai jenis olahan makanan lainnya. Hampir di seluruh Kecamatan di Kabupaten Sukabumi memproduksi makanan. Hal ini mengingat bahwa masyarakat Kabupaten Sukabumi yang rajin, kreatif, 
dan selalu ingin berkembang. Selain itu, Kabupaten Sukabumi juga memiliki potensi sumber daya alam yang cukup berlimpah.

Hasil olahan makanan para UMKM Kabupaten Sukabumi dipasarkan baik ditingkat lokal, nasional, maupun internasional. Permintaan hasil olahan Kabupaten Sukabumi di berbagai daerah, tingkat nasional maupun tingkat internasional terus mengalami peningkatan seiring dengan meningkatnya jumlah penduduk pada suatu daerah ataupun negara. Daya serap tenaga kerja pada komoditi ini juga cukup besar. Bentuk usaha olahan makanan di Kabupaten Sukabumi adalah berbentuk home industry.

Secara umum analisis rantai nilai dari produk olahan logam dapat dijabarkan sebagai berikut:

\section{Aktivitas Utama}

a. Logistik ke Dalam (Inbound Logistics)

Ketersediaan bahan baku untuk produksi di dapat dari pedagang distributor di Kabupaten Sukabumi, hingga saat ini tidak pernah mengalami kesulitan dalam mendapatkan bahan baku tersebut, meskipun ada beberapa bahan baku khusus yang didatangkan dari luar Kabupaten Sukabumi, namun harga bahan baku cenderung cepat meningkat. Lokasi industri pengolahan pada dasarnya masih merupakan usaha perorangan atau kelompok yang terkumpul dalam sentra industri logam Kabupaten Sukabumi.

b. Operasi/Produksi

Produksi-produksi pada saat ini sebagian besar masih menggunakan peralatan secara manual dan sebagian menggunakan teknologi pengecoran dan mesin pembubutan yang berkembang. Produk olahan logam sebagian besar alat rumah tangga dan komponen kendaraan bermotor. Kekhasan produk olahan logam Kabupaten Sukabumi, secara kualitas lebih baik dibanding yang dihasilkan daerah lain.

Pengetahuan mengenai teknologi pengecoran dan pembubutan yang mudah difragmentasi oleh pelaku usaha baru, sehingga berpotensi menimbulkan citra daerah sebagai penghasil olahan logam.

c. Logistik ke Luar (Outbound Logistics)

Produk logam olahan yang dihasilkan dijual langsung ke pasar atau melalui pedagang pengumpul yang berasal dari wilayah Sukabumi maupun dari luar wilayah Kabupaten Sukabumi.

d. Pemasaran dan Penjualan

Akses informasi pasar masih terbatas pada pameran-pameran yang diadakan oleh dinas terkait.
Potensi pasar didaerahmasih cukup besar danmemiliki peluang yang cukup besar untuk dikembangkan ke luar daerah. Pelayanan

Penjaminan kualitas produk yang dijual dilakukan melalui penyortiran produk berdasarkan kualitas, menimbulkan kebutuhan pelatihan proses pengolahan agar terjadi peningkatan kualitas produk.

\section{Aktivitas Pendukung}

a. Infrastruktur Perusahaan

Infrastruktur pendukung industri pengolahan logam Kabupaten Sukabumi, pada dasarnya melingkupi sarana akses jalan darat menuju lokasi usaha di Kabupaten Sukabumi dan kondisi infrastruktur energi listrik yang merupakan variabel penting dalam peningkatan produksi.

b. Manajemen Sumber Daya Manusia (MSDM)

Kinerja SDM dalam pengelolaan usaha membutuhkan tenaga kerja dengan keterampilan manajerial yang memadai. Pekerja berasal dari masyarakat sekitar dengan kriteria unskilled maupun skilled yang kemudian dilatih secara langsung atau dituntun oleh pekerja yang sudah lama berkerja.

Penerapan manajemen usaha yang lebih modern akan mendukung perkembangan usaha. Dapat dijadikan usaha andalan/mata pencaharian masyarakat dalam pemberdayaan ekonomi kerakyatan terutama bagi masyarakat petani sebagai alternatif kegiatan ekonomi bernilai tambah tinggi.

Untuk UMKM, dijelaskan bahwa proses pengembangan produk yang masih buruk. Oleh karena itu, sangat sedikit informasi yang tersedia tentang bagaimana berhasil merancang, mengembangkan, dan memasarkan produk baru di UMKM. Usaha kecil yang dibatasi oleh keterbatasan pengetahuan, sumber daya dan keterampilan. Namun, di sisi lain mereka harus terus mengembangkan produk baru untuk mempertahankan pertumbuhan mereka (Senk et al., 2010).

c. Pengembangan Teknologi

Pengembangan teknologi produksi relatif lambat berkembang dan lebih banyak menggunakan proses produksi secara manual dan tradisional. Sistem penyediaan dan pelatihan tenaga kerja dalam penggunaan teknologi dapat diperoleh di lingkungan industri tersebut melalui sistem pemagangan.

d. Pengadaan Barang

Pengadaan bahan baku dilakukan sesuai kebutuhan. Ketersediaan bahan baku di pasar-pasar 
lokal di Kabupaten Sukabumi membuat jaminan bahan baku terjaga. Bahan-bahan khusus yang didatangkan dari luar Kabupaten Sukabumi juga sudah tertata dalam jaringan usaha yang baik.

Tidak terdapat gudang penyimpanan untuk menyimpan bahan baku dalam waktu yang panjang karena bahan baku yang ada langsung digunakan. Terdapat gudang penyimpanan hasil produksi untuk sementara yang cukup memadai.

Dari penjelasan yang telah disampaikan, maka dapat diperoleh kesimpulan awal dari rantai nilai olahan logam adalah bahwa sub aktivitas yang memberikan kontribusi nilai tambah yang penting di Kabupaten Sukabumi berasal dari aktivitas utama dan pendukung. Sub aktivitas utama yang memberikan kontribusi penting dalam penciptaan nilai tambah adalah sub aktivitas operasi/produksi, sedangkan sub aktivitas pendukung berasal dari manajemen SDM yang sangat berkaitan dengan proses produksi yang dilakukan. Dengan justifikasi ini maka dipilihlah aktivitas rantai nilai proses produksi sub aktivitas operasi/produksi dan aktivitas pengembangan teknologi.

\section{Prioritas Produk Unggulan UMKM Perdagangan dan Jasa}

Jasa perbengkelan di Kabupaten Sukabumi telah terkenal di berbagai daerah. Jenis jasa perbengkelan di kabupaten Sukabumi diantaranya, jasa las, jasa bengkel motor, jasa bengkel mobil, dan berbagai jasa perbengkelan lainnya. Permintaan jasa perbengkelan di Kabupaten Sukabumi pun setiap tahunnya terus mengalami peningkatan seiring dengan meningkatnya barang-barang otomotif dan elektronik lainnya. Jasa perbengkelan di Kabupaten Sukabumi sangat diminati oleh para UMKM di Kabupaten Sukabumi. Hal ini dikarenakan omzet usaha ini cukup besar dan prospek usaha ini yang sangat menjanjikan.

Begitu juga dengan pedagang eceran, jumlah pedagang eceran di Kabupaten Sukabumi terus meningkat. Hal ini disebabkan karena usaha ini dapat dilakukan tanpa harus mengeluarkan modal yang sangat besar. Selain itu, usaha ini juga dapat dijalankan di mana saja baik di depan rumah, ruko, maupun tempat usaha lainnya. Keberadaan usaha ini berada di seluruh kecamatan yang ada di Kabupaten Sukabumi dan mayoritas yang menjalankan usaha ini adalah para ibu rumah tangga yang berada di rumah.
Usaha jasa dan perdagangan lainnya yang cukup marak di Kabupaten Sukabumi adalah penjahit. Usaha ini dilakukan di berbagai rumah penduduk. Usaha ini tersebar di berbagai kecamatan di Kabupaten Sukabumi. Usaha ini mayoritas melibatkan tenaga kerja yang berasal dari kelurga, meskipun terkadang ada juga UMKM yang mengambil tenaga kerja yang berasal dari luar keluarga. Permintaan jasa penjahitan di Kabupaten Sukabumi terus mengalami peningkatan. Seiring dengan meningkatnya mode dalam berbusana. Apalagi jika menjelang hari raya besar seperti, hari raya Idul Fitri. Hal tersebut berdampak terhadap omzet penjualan, omzet usaha ini ketika menjelang hari raya Idul Fitri pun mengalami peningkatan dua hingga tiga kali lipat dari hari biasanya. Selain itu, permintaan jasa jahitan ini pun terkadang ada yang berasal dari luar daerah Kabupaten Sukabumi. Modal usaha pada usaha ini pun tidak memerlukan modal yang cukup besar.

Begitu juga untuk percetakan, keberadaan usaha percetakan di Kabupaten Sukabumiterus menampakan geliatnya. Banyak UMKM di Kabupaten Sukabumi yang menjalankan usaha ini. Setiap tahunnya, usaha percetakan ini terus mengalami peningkatan seiring dengan meningkatnya permintaan masyarakat akan pentingnya dunia pendidikan. Omzet usaha ini juga sangat besar, dan mampu menyerap tenaga kerja yang cukup besar.

Selain usaha jasa perbengkelan, pedagang eceran, penjahit, dan percetakan, sebagian besar para UMKM di Kabupaten Sukabumi juga menggeluti usaha salon. Banyak UMKM di Kabupaten Sukabumi yang menggeluti usaha ini. Setiap tahunnya, usaha salon ini terus mengalami peningkatan seiring dengan meningkatnya permintaan masyarakat akan model dalam tatanan rambut, mode dalam penampilan, kebutuhan dalam rias pengantin atau hari-hari besar, dan lain sebagainya.

Secara umum analisis rantai nilai dari jasa perbengkelan dapat dijabarkan sebagai berikut:

\section{Aktivitas Utama}

a. Logistik ke Dalam (Inbound Logistics)

Ketersediaan bahan baku untuk produksi di distributor spare part yang ada di Kabupaten Sukabumi, hingga saat ini tidak pernah mengalami kesulitan dalam mendapatkan bahan baku tersebut, meskipun ada beberapa bahan baku khusus yang 
didatangkan dari luar Kabupaten Sukabumi, namun dapat disediakan oleh beberapa pengusaha yang ada di Kabupaten Sukabumi. Lokasi usaha pada dasarnya masih merupakan usaha perorangan atau kelompok yang tersebar hampir diseluruh kecamatan yang ada di Kabupaten Sukabumi.

\section{b. Operasi/Produksi}

Jasa perbengkelan pada saat ini sebagian besar masih menggunakan peralatan secara manual dan ada sebagian yang modern mengikuti perkembangan teknologi kendaraan bermotor yang terus berkembang. Core bisnis jasa perbengkelan adalah pada layanan yang baik terhadap konsumen. Kekhasan pelayanan tidak jauh berbeda dibanding daerah lain. Pengetahuan mengenai teknologi perbengkelan yang mudah difragmentasi oleh pelaku usaha baru, sehingga berpotensi menimbulkan citra daerah jasa perbengkelan.

\section{c. Logistik ke Luar (Outbound Logistics)}

Pengguna jasa perbengkelan sebagian besar berasal dari wilayah Sukabumi dan ada sebagian dari luar wilayah Kabupaten Sukabumi.

\section{d. Pemasaran dan Penjualan}

Akses informasi pasar masih terbatas pada papan iklan nama bengkel yang ada di lokasi usaha. Kecenderungan pasar akan terus meningkat seiring peningkatan jumlah kendaraan bermotor yang tumbuh pesat. Hal ini sejalan dengan penelitian Munizu (2010) yang mengemukakan kegiatan promosi yang dilakukan oleh pengusaha frekuensinya sangat jarang, bahkan beberapa pengusaha tidak pernah mempromosikan produknya di masyarakat.

\section{e. Pelayanan}

Kualitas pelayanan menjadi faktor penting dalam menjaga pasar, menimbulkan kebutuhan pelatihan bagi tenaga kerja untuk meningkatkan keterampilan pelayanan pada konsumen.

\section{Aktivitas Pendukung}

a. Infrastruktur Perusahaan

Infrastruktur pendukung jasa perbengkelan Kabupaten Sukabumi, pada dasarnya melingkupi sarana transportasi, infrastruktur energi dan telekomunikasi. Trend kenaikan harga energi menjadi kendala pengembangan usaha.

b. Manajemen Sumber Daya Manusia (MSDM)

Kinerja SDM dalam layanan perbengkelan membutuhkan tenaga kerja dengan keterampilan yang memadai. Pekerja berasal dari masyarakat sekitar dengan kriteria unskilled maupun skilled yang kemudian dilatih secara langsung atau dituntun oleh pekerja yang sudah lama berkerja.

Penerapan manajemen usaha sederhana dan bersifat tradisional/usaha keluarga. Dapat dijadikan usaha andalan/mata pencaharian masyarakat dalam pemberdayaan ekonomi kerakyatan terutama bagi masyarakat sebagai alternatif kegiatan ekonomi bernilai tambah tinggi.

c. Pengembangan Teknologi

Pengembangan teknologi yang relatif lambat berkembang dan lebih banyak menggunakan proses pelayanan secara manual dan tradisional. Sistem penyediaan dan pelatihan tenaga kerja dapat diperoleh di lingkungan industri tersebut melalui pemagangan. Padahal di era knowledge-based economy saat ini adalah penting bagi UMKM untuk melakukan adopsi teknologi informasi, karena adopsi teknologi informasi memberikan kemampuan bagi UKM untuk memberikan layanan yang semakin baik dan daya saing (Apulu dan Latham, 2011). Hal ini juga sejalan dengan hasil penelitian yang dilakukan oleh Kleindl (2000) bahwa tantangan untuk UMKM adalah gradasi teknologi.

d. Pengadaan Barang

Pengadaan bahan baku dilakukan sesuai kebutuhan. Ketersediaan bahan baku di pasar-pasar lokal di Kabupaten Sukabumi membuat jaminan bahan baku terjaga. Bahan-bahan khusus yang didatangkan dari luar Kabupaten Sukabumi juga sudah tertata dalam jaringan usaha yang baik. Terdapat gudang penyimpanan untuk menyimpan spare part dalam waktu yang panjang.

Dari penjelasan yang telah disampaikan, maka dapat diperoleh kesimpulan awal dari rantai nilai jasa perbengkelan adalah bahwa sub aktivitas yang memberikan kontribusi nilai tambah yang penting dalam jasa perbengkelan di Kabupaten Sukabumi berasal dari aktivitas utama dan pendukung. Sub aktivitas utama yang memberikan kontribusi penting dalam penciptaan nilai tambah adalah sub aktivitas pelayanan, sedangkan sub aktivitas pendukung berasal dari pengembangan teknologi yang sangat berkaitan dengan proses produksi yang dilakukan. Dengan justifikasi ini, maka dipilihlah aktivitas rantai nilai proses produksi sub aktivitas pelayanan dan aktivitas pengembangan teknologi. 


\section{KESIMPULAN}

Hasil identifikasi potensi unggulan produk UMKM Kabupaten Sukabumi menunjukkan, bahwa potensi unggulan produk UMKM di setiap sektor berdasarkan kriteria jumlah unit usaha, potensi pengembangan, dan isu strategis pengembangan produk daerah adalah sektor pertanian: terdiri dari produk manggis, ikan hias, sapi potong, ikan laut, kelapa. Sektor industri pengolahan: terdiri dari produk olahan logam, batu aji, tanduk, alat peraga pendidikan, dan makanan. Sektor perdagangan dan jasa: terdiri dari produk jasa perbengkelan, pedagang eceran, penjahit, percetakan, salon. Kemudian, setelah dilakukan analisis AHP berdasarkan kriteria keunikan, potensi pasar, dan manfaat ekonomi, maka dapat diidentifikasi potensi unggulan produk UMKM prioritas adalah manggis, pengolahan logam, dan jasa perbengkelan.

Dalam analisis rantai nilai, teridentifikasi penciptaan nilai tambah yang tinggi dalam pengembangan produk dilihat dari aktivitas utama dan pendukung menunjukkan bahwa dalam produk unggulan prioritas manggis aktivitas operasi/produksi dan aktivitas sumber daya manusia merupakan variabel penting dalam penciptaan nilai tambah. Dalam produk unggulan prioritas olahan logam variabel penting dalam penciptaan nilai tambah produksi adalah pengembangan teknologi dan operasi produksi. Dalam produk unggulan prioritas jasa perbengkelan variabel penting dalam penciptaan nilai tambah adalah pengembangan teknologi dan pelayanan terhadap konsumen.

\section{DAFTAR PUSTAKA}

Apulu, Idisemi \& Ann Latham. 2011. Drivers for Information and Communication Technology Adoption: A Case Study of Nigerian Small and Medium Sized Enterprises. International Journal of Business and Management, 6(5): 51-60.
Cheng, E. W. L. \& Li, H. 2001. Information PrioritySetting for Better Resource Allocation Using Analytic Hierarchy Process (AHP). Information Management and Computer Security, (2): 61-70.

Demirbag, M., E. Tatoglu, M. Tekinkus, \& S. Zaim. 2006. An analysis of the relationship between TQM implementation and organizational performance: evidence from Turkish SMEs. Journal of Manufacturing Technology Management, 17(6) 829-847.

Drake, P. R. 1998. Using the Analytical Hierarchy Process in Engineering Education. International Journal of Engineering Education, 14(3): 191196.

Kleindl, B. 2000. Competitive Dynamics and New Business Models for SMEs in The Virtual Marketplace. Journal of Developmental Entrepreneurship, 5(1): 73-85.

Kutlu, B., \& M. Özturan. 2008. The Usage and Adoption of IT among SMEs in Turkey: An Exploratory and Longitudinal Study. Journal of Information Technology Management, 19(1).

Mateja Karnicar Šenk, Peter Metlikovic, Matjaž Maletic, \& Boštjan Gomišcek. 2010. Development of New Product/Process Development Procedure for SMEs. Organizacija, 43(2): 76-85.

Munizu, Musran. 2010. PengaruhFaktor-Faktor Eksternal dan Internal Terhadap Kinerja Usaha Mikro dan Kecil (UMK) di Sulawesi Selatan. Jurnal Manajemen dan Kewirausahaan, 12(1): 33-41.

Ongori, H. 2009. Role of Information Communication Technologies Adoption in SMES: Evidence from Botswana. Research Journal of Information Technology, 1(2): 79-85.

Saaty, T. L. 1994. How to Make a Decision: The Analytic Hierarchy Process. Interfaces, 24: 19-43. Singh, Rajesh K., Suresh K. Garg, dan S.G. Deshmukh. 2008. Strategy Development by SMEs for Competitiveness: a Review. Benchmarking: An International Journal, 15(5): 525-547. 